molecules en route for the membrane, and in increasingly complete stages of assembly, will be found in the endoplasmic reticulum, Golgi and cytoplasmic vesicles. Reservoirs of a number of molecules destined for the cell membrane and showing modified immunoreactivity, enzymatic potential or binding properties have been identified intracellularly ${ }^{11-15}$. A recent example, relevant to this discussion, is the identification of a saxitoxin-binding protein in frog heart cytosol as a putative sodium channel ${ }^{16}$. Amiloride analogues have been used to identify components in sodium-transporting epithelia with properties consistent with those of apical sodium channels. Binding measurements in intact tissues, such as frog skin ${ }^{17}$, have given site densities $\left(130 \mu \mathrm{m}^{-2}\right)$ comparable with fluctuation analysis ${ }^{18}\left(50 \mu \mathrm{m}^{-2}\right)$. However, in isolated cells ${ }^{19}$ and homogenates ${ }^{20}$ where the ligands have access to intracellular sites, much greater site densities have been obtained. Finally, in the epithelium lining the avian coprodaeum, rod-shaped particles, tentatively identified as sodium channels, have been seen in freeze-fractured membranes, both apical and intracellular ${ }^{21}$.

Thus there is a body of very different sorts of evidence which suggests that transporting epithelia have a reservoir of vesicles containing sodium channels poised for insertion into the apical membrane. Whether these vesicles can ' $k$ iss and make up' the increase in sodium permeability of the apical surface in response to punching may be very hard to prove.

\title{
Inhumation: how ants and other invertebrates help seeds
}

\section{from Andrew J. Beattie and David C. Culver}

WHAT happens to seeds once tl ey come to rest following dispersal? Seeds are scattered widely in the environment by wind, water, animals and explosive mechanisms and yet the sites where successful germination and growth can occur are often patchy, scarce and limiting ${ }^{1,2}$. Some possess mechanisms such as hygroscopic bristles for self-burial ${ }^{3}$, while others are effectively buried by falling into soil crevices or where wind- or water-borne soil and debris accumulate ${ }^{2}$. Many seeds do not require burial for germination, but a common fate for those remaining on an exposed surface is to be eaten ${ }^{4}$. Are there mechanisms that increase the probability with which they will end up in a better site?

Recent work on ant dispersal of seeds (myrmecochory) strongly suggests that a major selective advantage is provided by the relocation of seeds to ant nests which are richer than surrounding soils in essential nutrients such as phosphorus, potassium and nitrogen ${ }^{5.7}$. Seeds end up on the soil or litter surface following dispersal and are then removed by ants which are attracted to nutritious tissues (elaiosomes) on the seed coat. Once in the nest, the elaiosomes are removed and the seeds abandoned, intact and viable, either in an old gallery or in the refuse pile ${ }^{8}$.

In a series of experiments with two myrmecochorous species of Viola, the fates of seeds taken into nests by ants were compared with the fates of seeds planted at random in the same habitats and it was found that seedling emergence is nearly

Andrew J. Beattie and David C. Culver are in the Department of Ecology and Evolutionary Biology, Northwestern University, Evanston, Illinois 60201 . three times more likely from nests. Furthermore, the seedlings emerging from ants nests are larger, and the probability of their surviving the first two years is considerably higher $(0.14 \text { against } 0.03)^{7,9}$.

Additional ant-mediated effects appear in a study of another myrmecochore, Sanguinaria canadensis. This species can persist in disturbed habitats, where the primary ant dispersers are absent, by means of vegetative propagation but, in undisturbed forests, where seed-dispersing ants are present, profound changes in adult density, dispersion and patterns of reproduction are brought about ${ }^{10}$. Further beneficial effects also come from the greater chance that seeds relocated to nests will escape the attention of predators 4,11 .

Myrmecochory may be much more widespread than has been thought. European and North American temperate deciduous forests and Australian sclerophyll shrublands have often been regarded as its lone strongholds ${ }^{12,13}$, but we now know that it occurs commonly in a very wide variety of plant community types worldwide, from low to high latitudes and elevations in both the Northern and Southern Hemispheres ${ }^{9}$. Myrmecochorous species are known from 80 plant families (including grasses and cacti) and may be trees, shrubs, vines, herbaceous perennials, annuals, hemiparasites, parasites and epiphytes. Myrmecochores constitute 35 per cent of species in certain habitats, and up to 76 per cent of emergent stems ${ }^{13-15}$

Invertebrate groups other than ants may have similar effects on the fate of seeds. Scarab beetles (Scarabeidae) in the Cerrado of Brazil collaborate to roll and bury fruits. The larvae mature by eating the pulp and the viable, intact seeds remain below ground ${ }^{16}$. Ground beetles (Carabidae), common in many habitats ${ }^{17.18}$, store seeds in the lining of their tunnels. The function of this behaviour is obscure, but the seeds appear to remain unharmed ${ }^{19-21}$

Earthworm burrows and casts are known to be richer in critical plant nutrients than surrounding soils 5,22 and many kinds of seeds are passed intact and viable embedded into the cast ${ }^{23}$. Snails too may be of importance. A series of experiments in which seeds were placed with captive snails showed that the overwhelming majority pass through the digestive tract to be deposited in the faeces intact.

We suggest 'inhumation' (Latin: humare $=$ to cover with earth) may provide a useful term for the process described above. While this process has been described for seeds passing through the guts of vertebrates such as birds, bats and various other mammals ${ }^{24-27}$, the inclusion of major and abundant invertebrate groups, such as ants, beetles, earthworms and snails, may make the process of inhumation far more important than previously supposed. Mortality in plant populations is generally greatest among seedlings deprived of suitable microsites or sufficient seed reserves. Inhumation may circumvent these dangers to some degree by increasing the probability that seeds are relocated to microsites already pı ovisioned with nutrients.

1. Solbrig, O. T., Jain, S., Johnson, G. B. \& Raven, P. H. Topics in Plant Population Biology (Columbia UniverTopics in Plant Population Bity

2. Harper, J. L. The Population Biology of Planis (Academic, New York, 1977).

3. van der Pijl, L. Principles of Dispersal in Higher Plants (Springer, New York, 1969).

4. Heithaus, E. R. Ecology 62, 136-145 (1981)

5. Petal, J. in Production Ecology of Ants and Termites (cd. Brian, M. B.) 293-325 (Cambridge University Press, Ncw York, 1978).

6. Davidson, D. W \& Morton, S. R. Oecologia 50, 357-366 (1981).

7. Culver, D. C. \& Beattic, A. J. Am. J. Bot. 60, 710-714 (1980).

8. Culver, D. C. \& Beattic, A. J. J. Ecol. 66, 53-72 (1978).

9. Beattie, A. J. Abh. Verh. naturw. Ver. Hamburg (in the press).

10. Pudlo, R. J., Beattie, A. 3.\& Culver, D. C. Oecologia 146 $32-37$ (1980).

1. O'Dowd, D. I. \& Hay, M. E. Ecology 61, $531-540$ (1980)

12. Serander, R. K. sienska Vetensk-Akad. Handl. 41, 1-410 (1906).

13. Berg, R. Y. Aust. J. Bot. 23, 475-508 (1975).

4. Beattie, A. J. \& Culver, D. C. Ecology 62, 107-115 (1981).

15. Handel, S. N., Fisch, S. B. \& S hatz, G. E. Bull. Torrey bot. C/ub 108, 430-437 (1981).

16. Gottsberger, G. K. Abh. Verh. naturw. Ver. Hamburg (in the press)

17. Schaller, F. Soil Animals (University of Michigan Press, Ann Arbor, 1968).

18. Borror, D. J., Del.ong, D. M. \& Triplehorn, C. A. An Introduction to the Study of Insects, 4th edin (Holt, Rinchart \& Winston. Ncw York, 1976).

19. Alcock, J. Bull ecol. Soc. Am. 54, 45-46 (1973)

20. Kirk. V. M. Ann. ent. Soc. Am. 65, 1426-1428 (1972); 66 , 513-518(1973)

1. Manlcy, G. V. Ann. ent. Soc. Am. 64, 1474-1475 (1971).

22. Edwards, C. A. \& L lofly, J. R. J. appl. Ecol. 17. $533-543$ (1980).

23. McRill, M. \& Sagar, (i. R. Nature 243, 482 (1973).

24. Ridlcy, H N. The Dispersal of Plants Throuphout the World (Reeve. Ashford. 1930).

25. Mekev, D. The Coevolution of Animais and Plants teds Gilbert, L. E. \& Raven, P. H.) 159.191 (University of Gilbert, l. E. \& Raven, Texas Press, Austin, 1975)

26. I icberman, D., Hall, 3. B., Swainc, M. D. \& Licberman. M. Ecology 60. 65-75 (1979).

27. Janzen, D. H. Ecology 62, 593-601 (1981). 